\title{
Parental divorce, Interparental conflict, and Parent-child relationships in Spanish young adults
}

\author{
Klara Smith-Etxeberria and Amaia Eceiza
}

Department of Developmental Psychology, College of Psychology, University of the Basque Country (Spain)

\begin{abstract}
Título: Divorcio parental, conflicto interparental y relaciones parentofiliales en adultos jóvenes españoles.

Resumen: El principal objetivo de este estudio fue analizar las asociaciones entre el divorcio parental y el conflicto interparental con la calidad de las relaciones paterno-filiales y materno-filiales, en una muestra española de 1078 adultos jóvenes. También se analizó la función moderadora del género de estos adultos jóvenes. Nuestros resultados sugirieron que el conflicto interparental se asocia con relaciones paterno-filiales y materno-filiales de menor calidad, mientras que el divorcio parental se asocia de forma más negativa con la calidad de la relación con el padre que con la madre. Además, el género de los hijos adultos únicamente moderó la asociación entre el divorcio parental y la calidad de las relaciones paterno-filiales, de manera que las mujeres de familias divorciadas obtienen puntuaciones más bajas en la calidad de la relación paterno-filial que las mujeres de familias no divorciadas. Los resultados aportan mayor información a la literatura empírica existente y promueven una mejor comprensión de las asociaciones complejas existentes entre el divorcio y conflicto parental con la calidad de las relaciones parento-filiales, en un contexto cultural donde hay escasa investigación sobre el tema.
\end{abstract}

Palabras clave: Divorcio parental. Conflicto interparental. Relaciones parento-filiales. Joven adultez.

\begin{abstract}
The main aim of this study was to analyze the associations between parental divorce and interparental conflict with father-child and mother-child relationship quality, in a Spanish young adult sample. The moderating effect of adult child's gender was also analyzed. Using a sample of 1,078 Spanish young adults, our results suggested that interparental conflict was more strongly associated with lower mother-child and fatherchild relationship quality, and that parental divorce was more strongly associated with father-child relationship quality than with mother-child relationship quality. In addition, adult child's gender only moderated the effect of parental divorce on father-child relationship quality, such that women from divorced families score lower on father-child relationship quality than women from non-divorced families. Findings add to the existing literature and promote a better comprehension of the complex associations between parental divorce and conflict with parent-child relationship quality in an understudied cultural context.

Keywords: Parental divorce. Interparental conflict. Parent-child relation-
\end{abstract} ships. Young adulthood.

\section{Introduction}

A great body of research suggests that parental divorce is associated with negative outcomes on both children and adult children, such as lower wellbeing, insecure attachment styles, dissatisfying romantic relationships, and negative parentchild relationships (Amato, 2001; Cui \& Fincham, 2010). Given that in Spain divorce has only been legally possible since 1981, in comparison to other countries, less attention has been given to the study of the effects of parental divorce on Spanish young adult children. Likewise, continued exposure to parental conflict has been associated with negative outcomes in both mother-child and father child relationships during young adulthood (e.g. Riggio \& Valenzuela, 2011). When comparing the effects of parental divorce and interparental conflict, a few studies have concluded that, in the long-term, parental conflict is associated with more negative relationships with both parents, whereas parental divorce is especially associated with more negative father-child relationships (e.g. Riggio, 2004). The purpose of our study is to examine how current mother-child and father-child relationship quality are associated with parental divorce and interparental conflict in young adulthood. In the study of the effects of these family experiences, beyond analyzing the differential

* Correspondence address [Dirección para correspondencia]:

Klara Smith-Etxeberria, Departamento de Procesos Psicológicos Básicos y su Desarrollo. Avda. Tolosa 70, Campus Gipuzkoa. 20018 San Sebastian (Spain). E-mail: klara.smith@ehu.eus

(Article received: 28-09-2018; revised: 14-06-2019; accepted: 22-10-2019) effects of parental divorce and conflict it is necessary to analyze their interactive effect. Thus, we also analyze the interaction between parental divorce and conflict. In addition, given that in the study of these family experiences controversial results have been found regarding the role of child's gender, adult child's gender will be analyzed as a moderator in the effects of these family experiences.

\section{Parental divorce}

Attachment theory suggests that negative family experiences can affect parents' sensitivity to their children's needs and, thus, on the quality of parent-child relationships (Bowlby 1969). Indeed, existing literature confirms that parental divorce is associated with less secure parent-child ties during young adulthood (Amato, 2001). Although young adulthood is characterized by a greater emotional autonomy towards parents, parents are still important figures in the transition to this period, as young adults still depend on their parents as an economic resource, but also for emotional support and advice (Arnett, 2015). Relationships with parents during this developmental period have been defined with positive and negative emotions, such as love, thankfulness, acceptance, disappointment, resentment and mistrust (Arnett, 2015). Parental divorce is an emotionally stressful and complex transition for families and it can affect children, even until adulthood. Given that young adulthood is a stage of crisis, it is more likely for adult children that have experienced parental divorce to have less positive relationships with their parents 
than those that have not gone through this family experience (Arnett, 2015).

Given that divorce causes significant changes in the family structure, it might influence negatively the sensitive responsiveness and physical and psychological availability of parents as primary caregivers (Feeney \& Monin, 2016). Children from divorced families raised in shared custody have better relationships with both parents and especially with their fathers, than when they are raised in sole custody, mainly maternal (Bauserman, 2002; Nielsen, 2011). However, prior to and following divorce, children usually suffer from the deterioration in parenting of both custodial and non-custodial parents, because of the stressors associated with divorce (Hetherington \& Kelly, 2002). During the first years after divorce, parents are usually preoccupied with their own emotional responses to divorce (Hetherington \& Kelly, 2002). This can lead to a diminished parenting of the custodial parent, who is usually the mother (Hetherington \& Kelly, 2002). Therefore, children can experience less positive involvement from their custodial parent, such as less sensitivity (Kelly \& Emery, 2003). In addition, after divorce, children usually suffer from the loss or diminished contact with their non-custodial parent, who is usually the father. This might lead children to have a diminished view of their fathers as a secure base and safe heaven, and to a decrease in closeness in the relationship with their father (Bartell, 2006; Kelly \& Emery, 2003). Thus, following divorce, parents might fail to provide an effective caregiving function to their children, such that the child may become a major caregiver for the parent or the parent may become psychologically and/or physically unavailable to the child (Feeney \& Monin, 2016).

Overall, several studies suggest that children of divorce frequently report not feeling affectively close to none of their parents or to only one of their parents, whereas children from non-divorced families usually report close and satisfying relationships with both parents (Amato, 1994; Amato \& Booth, 1996; Amato \& Sobolewski, 2001; Booth \& Amato, 1994; Sobolewski \& Amato, 2007).

The quality of parent-child relationships has also been considered a key mediator between parental divorce and children's later adjustment, due to the modifications attachment relationships with parents suffer in the post-divorce period (Amato, 2000; Amato \& Sobolewski, 2001). That is, adult children of divorce have less contact with their parents, they exchange less help behaviors with them, and they describe the relationships with their parents in a more negative way, which in turn has been associated with lower wellbeing levels in young adulthood (e.g. Amato \& Sobolewski, 2001). Furthermore, longitudinal studies have found that stressful life events, such as parental divorce, may lead to parent-child attachment changes in early adulthood, which, in turn, might influence adult children's romantic attachment (Waters et al., 2000). A less positive involvement from the custodial parent following divorce might also lead children to be less socially competent and have more negative views of intimate rela- tionships (Bartell, 2006; Kelly \& Emery, 2003). In addition, the loss or diminished contact with the non-custodial parent might lead to a decrease in closeness in the relationship with their father due to his lower emotional availability. These changes in father-child relationships might be associated with young adults' lower wellbeing and more negative relationship attitudes (Bartell, 2006; Kelly \& Emery, 2003).

Although some studies have exclusively examined the impact of parental divorce on parent-child relationships (e.g. Booth \& Amato, 2001), scarce studies have examined its effect separately on father-child and mother-child relationships. A number of studies suggest that father-child relationships are more affected by divorce (Amato 2014), such that divorce seems to affect more negatively adult children's relationships with their father than with their mother (Amato \& Booth, 1996; King, 2002). In addition, adult children of divorce seem to have a more secure attachment with their mother than with their father (Carranza et al., 2009; Fraley \& Heffernan, 2013; Hannum \& Dvorak, 2004). Indeed, a few studies have even suggested that adult children of divorce report more affective quality, independence and emotional support with their mothers than children from non-divorced families (Riggio, 2004; Riggio \& Valenzuela, 2011). According to Riggio, this positive effect in mother-child relationships might be due to the fact that mothers and children, who usually cohabit in the post-divorce period, struggle to adapt to changes accompanying divorce, leading adult children of divorce to develop a closer and more satisfying relationship with their mothers. However, a few longitudinal studies still suggest that parental divorce is negatively associated with mother-child relationships due to interparental conflict and a disrupted parenting (Wallerstein et al., 2013), and that maternal sensitivity is lower in mother-child dyads in divorced families compared to non-divorced families (Sutherland et al., 2012). Given the inconsistent results regarding the effects of parental divorce on father-child and mother-child relationships, more empirical research is needed to clarify this issue especially in young adulthood.

Regarding the differential effects of parental divorce by child's gender on both father-child and mother-child relationships, some studies have not found an interactive effect between parental divorce and child's gender on the qualities of relationships with either fathers or mothers (Lee, 2018). Nevertheless, others have found that opposite sex parentchild ties are more deteriorated by parental divorce in adulthood. That is, daughters report lower closeness in the relationships with their fathers, whereas sons report lower closeness in the relationships with their mothers (Booth \& Amato, 1994). However, other studies have found more negative consequences for the same sex parent-child dyads. In other words, some studies suggest that boys are more distressed than girls by separation from their fathers because of their strong identification with the same-sex parent (Hetherington \& Kelly, 2002). Girls of divorce instead seem to be more likely to feel responsible for their father's well-being when their parents engage in conflict (Bretherton \& Page, 
2004; Cooney et al., 1995). For example, Cooney et al. (1995) found that daughters report lower intimacy levels in the relationships with their mothers, when they mediate in parental disputes and when they advise their fathers during the divorce process. These divorce process variables were, in turn, associated with higher intimacy levels with their father. However, to our knowledge, the association between parental divorce and mother-child and father-child relationships, depending on adult child's gender, has not been tested in young adults from a country where divorce is a relatively new family experience.

\section{Interparental conflict}

Children's perception of high levels of interparental conflict may also be associated with children's lower family satisfaction (Iraurgi et al., 2011), such that adult children's relationships with their parents can also be altered by being exposed to conflictive interactions between their parents. The spillover hypothesis in the family systems theory suggests that marital conflict might spill over affecting parent-child relationships negatively, as parents might reproduce the marital hostility and aggressiveness in the relationships with their children (Sturge-Apple et al., 2006). In addition, given that parental stress related to conflict might hinder parents' ability to be sensitive, warm and responsive to their children needs, marital conflict might also explain more negative parent-child interactions in young adulthood (Sturge-Apple et al., 2006).

Interparental conflict has been negatively associated with both father-child and mother-child relationship quality in adulthood (Riggio, 2004; Riggio \& Valenzuela, 2011), such as lower affective quality, independence, and emotional support in both father-child and mother-child relationships (Riggio, 2004). A few studies also suggest that adult children who report low levels of parental conflict show a more secure attachment with both parents, whereas those who report high conflict levels show more insecure attachment relationships with both parents (Hannum \& Dvorak, 2004; Ross \& Fuertes, 2010). In addition, high levels of trust and communication and parent-child attachment relationship quality have been negatively associated with perceived frequency, intensity and resolution of interparental conflict, and with both perceived threat and self-blame in the presence of interparental conflict (Ross \& Fuertes, 2010).

Empirical research has also shown that parent-child relationship quality is a key mediator between parental conflict and adult children's adjustment. That is, parental conflict has been associated with children's feelings of keeping a less close relationship with both parents (Booth \& Amato, 1994; Sobolewski \& Amato, 2007), which, in turn, has been associated with a greater risk for adult children to suffer from distress, lower self-esteem and general unhappiness (Booth \& Amato, 2001). Likewise, parental conflict has been associated with higher parent-child alienation (Monè \& Biringen, 2006) and a higher likelihood of feeling caught between parents, which, consequently, has been associated with children's lower wellbeing (Amato \& Afifi, 2006).

Regarding child gender differences, empirical research shows controversial results in the associations between interparental conflict and parent-child relationships. Although some authors have not found gender differences (e.g. Hayashi \& Strickland, 1998), a few studies indicate that parental conflict has more harmful effects for the opposite parent-child sex dyads than for the same-sex dyads (Amato \& Booth, 1996; Booth \& Amato, 1994). For example, it has been found that parental conflict is associated with lower closeness and support in father-daughter relationships, but not in father-son relationships (Booth \& Amato, 1994). Other studies, however, have found worse consequences of parental conflict for the same-sex parent-child dyads. That is, feeling caught between parents during parental conflict has more damaging effects for the mother-daughter dyad (Amato \& Afifi, 2006). In addition, for example, Henry and Holmes (1997) found that parental conflict was associated with more negative father-son relationships as they described their fathers as not being emotionally available and responsive to their needs, whereas they reported better relationships with their mother.

A very few studies have compared the effects of parental divorce with those of interparental conflict on parent-child relationship quality in young adulthood, by testing simultaneously their effect. Overall, both parental conflict and divorce are associated with more negative parent-child relationships (Amato \& Booth, 1996; Booth \& Amato, 1994). However, Monè, and Biringen (2006) for example posited that interparental conflict is associated with greater alienation in parent child-relationships, regardless of parental divorce. Children whose parents have a highly conflicted marriage are more likely to feel caught in the middle between their parents than those from divorced families (Amato \& Afifi, 2006). Some other investigations, instead, indicate differential effects of parental divorce and conflict for the quality of relationships with each parent. That is, parental conflict is associated with more negative mother-child and father-child relationships, whereas parental divorce is associated with more negative father-child relationships, in terms of affective quality, independence and emotional support (Hannum \& Dvorak, 2004; Riggio, 2004; Riggio \& Valenzuela, 2011).

Beyond comparing the effects of parental divorce and conflict on later parent-child relationship quality during adulthood, some studies have attempted to analyze their interactive effect (e.g. Yu et al., 2010). Although several studies have failed to find an interactive effect on parentchild relationship quality (Booth \& Amato, 2001; Monè \& Biringen, 2006; Riggio, 2004; Riggio \& Valenzuela, 2011), a few studies have found such interactive effect ( $\mathrm{Yu}$ et al., 2010). Indeed, Yu et al. (2010) found that divorce uniquely moderated the negative effects of interparental conflict on mother-daughter relationships. That is, in their study, interparental conflict in non-divorced families has a negative 
effect on mother-daughter relationships, and this effect is reduced when parents divorce. Further, parental divorce seemed to have a buffering effect on mother-daughter relationships when the parental marital relationship was characterized by high levels of conflict (Yu et al., 2010). This result is consistent with the stress-relief hypothesis (Wheaton, 1990), which suggests that divorce, as a stressful life experience, can benefit children if divorce is perceived as a way of escape from a stressful or dysfunctional environment. In this study, to test this hypothesis, we examine the interaction between parental divorce and interparental conflict.

\section{Overview of the current study}

By examining the role of parental divorce and interparental conflict on young adult children's relationships quality with their parents, we attempt to contribute to the literature in several ways. First, to our knowledge, limited attention has been given to the associations between parental divorce and conflict and their interactive effect on both father-child and mother-child relationship quality. Next, although the literature review suggests there might be differential effects by child's gender on the association between these family of origin experiences and parent-child relationships, results are not consistent. Thus, the moderating effect of child's gender is also tested in this study to shed further light on these discrepancies in young adulthood. Finally, limited attention has been given to the study of these effects in Spanish young adults. The following hypotheses are tested:

1. Parental divorce will be associated with low mother-child and father-child relationship quality in Spanish young adults.

2. Interparental conflict will be associated with low motherchild and father-child relationship quality in Spanish young adults.

3. Interparental conflict will be more strongly associated with low mother-child and father-child relationship quality than parental divorce. Further, interparental conflict and parental divorce will interact to explain both fatherchild and mother-child relationship quality, such that for young adults from non-divorced families, interparental conflict will be positively associated with low motherchild and father-child relationship quality to a greater degree than for young adults whose parents divorced.

4. Young adult child gender will moderate the association between parental divorce and parent-child relationship quality, and between interparental conflict and parentchild relationship quality.

\section{Method}

\section{Participants and Procedure}

Participants included undergraduate and vocational training school students from the Autonomous Community of the Basque Country in Spain. Respondents were informed in class about the main goals of the study and participated voluntarily after signing a consent form. All data were collected in person and all measures were administered in Spanish. This study was approved by the Ethics Committee in $\mathrm{Hu}$ man Research at the University of the Basque Country. Of the 1,106 students in the original sample, 1,078 reported on the variables of interest and had parents who were either living together or were divorced. The average age of respondents was 21.4 years, 50.5\% were women. Among the 1,078 participants $16 \%$ experienced parental divorce. Mean age at the time of divorce was 10.83 years. $72.8 \%$ mothers were the custodial parent.

\section{Measures}

Independent variables. Perceived interparental conflict was assessed with the adapted version to Spanish (Iraurgi et al., 2008) of the Children's Perception of Interparental Conflict Scale (Grych et al., 1992). All participants were asked to assess the level of conflict between their parents. Although recollections of marital unhappiness are associated with lower relationship quality with both parents (specially fathers) (Amato \& Booth, 1991), experiencing divorce when parents have a highly conflicted marriage might have less negative consequences on children, as divorce might be experienced as a way of escape from a dysfunctional family environment. On the other hand, children exposed to continued conflicts between parents might have worse consequences (Wheaton, 1990). Therefore, those who had experienced parental divorce were asked to report on parental conflict before divorce. The measure used included 12 items assessing the following sub-scales of interparental conflict: Perceived Frequency (Four items; e.g., 'My parents hardly ever argued or disagreed'), Intensity (Four items; e.g., 'My parents tended to get really angry when they argued or disagreed') and Resolution (Four items; e.g., 'When my parents argued, they usually worked things out'). For analysis purposes, we used the full scale, as these three sub-scales have been shown to reflect a single latent construct of perceived parental conflict (Grych et al., 1992). Each item had three possible responses: $0=$ true, $1=$ sort of true and $2=$ false. In this sample $\alpha$ for each subscale were $.84, .70$, and .78, respectively. Parental divorce was assessed by asking participants whether their parents were separated or divorced $(1=$ divorced, $0=$ not divorced $)$. Young adult gender was assessed by asking participants whether they were male (1) or female (0).

Dependent variables. Current parent-child relationships quality was assessed with the mother and father subscales of the Inventory of Parent and Peer Attachment (IPP A; Armsdem \& Greenberg, 1987). This measure assesses adolescents' and young adults' perceptions of the positive and negative affective/cognitive dimension of relationships with their parents. Each of these subscales consists of three factors: trust (Nine items; e.g., 'My mother/father respects my feeling'), communication (Nine items; e.g., 'I tell my mother/father about 
my problems and troubles') and alienation (Seven items; e.g., 'I get upset easily around my mother/father'). For analysis purposes, we used the full mother and father subscales. Responses to each item ranged from 1 (Almost never or never true) to 5 (Almost always or always true). Fit indices for the mother subscale were $\chi^{2}(249)=1711.91 ; p=.000$, RMSEA $=.081 ; \mathrm{NNFI}=.96 ; \mathrm{CFI}=.96 ; \mathrm{SRMR}=.056$. In addition, in the father subscale the fit indices were $\chi^{2}(249)=2091.28$; $p=.000$, RMSEA $=.095 ; \mathrm{NNFI}=.96 ; \mathrm{CFI}=.96 ;$ SRMR $=$
.064. In this sample $\alpha$ coefficients for the mother and father full scales were .92 and .90 , respectively.

Covariates. Age, relationship status (relationship $=1$; single $=0)$ and both parents' economic status (SES) as measured by their current occupation (Entrepreneurs or managers (High SES); professionals (medium-high SES) middle managers or technicians (Medium SES); factory workers (Medium-low SES); housework (low SES)) were included as covariates in the regression models.

Table 1. Descriptive information for study variables.

\begin{tabular}{|c|c|c|c|c|}
\hline Constructs & Indicators & $M(S D)$ or $n$ & Range & $\alpha$ \\
\hline \multirow{2}{*}{ Parental divorce } & No & 905 & ------ & ------ \\
\hline & Yes & 173 & ------ & ------- \\
\hline \multirow{3}{*}{ Interparental Conflict } & Frequency & $0.60(0.62)$ & $0-2$ & .84 \\
\hline & Intensity & $1.38(0.44)$ & $0-2$ & .70 \\
\hline & Resolution & $1.44(0.51)$ & $0-2$ & .78 \\
\hline \multirow{3}{*}{ Mother-child relationship } & Trust & $4.19(0.72)$ & $1-5$ & .90 \\
\hline & Communication & $3.72(0.79)$ & $1-5$ & .86 \\
\hline & Alienation & $2.35(0.72)$ & $1-5$ & .67 \\
\hline \multirow{3}{*}{ Father-child relationship } & Trust & $3.97(0.84)$ & $1-5$ & .92 \\
\hline & Communication & $3.17(0.89)$ & $1-5$ & .89 \\
\hline & Alienation & $2.50(0.78)$ & $1-5$ & .71 \\
\hline \multirow{2}{*}{ Young adult child gender } & Men & 534 & ------- & ------- \\
\hline & Women & 544 & ------- & ------- \\
\hline
\end{tabular}

\section{Data Analysis Plan}

Statistical analyses were conducted using IBM SPSS 24. To analyze the predictive ability of parental divorce and interparental conflict, and to test the moderating effect of child gender, a set of hierarchical multiple regressions were run on both mother-child and father-child relationship quality, accounting for covariates. Control variables, adult child gender (male) and parental divorce were entered in Model 1, in order to compare those from divorced families with those from non-divorced families. Model 2 included interparental conflict. In Model 3, two-way interactions between parental divorce and interparental conflict were added, and parental divorce $\mathrm{x}$ child gender and interparental conflict $\mathrm{x}$ child gender interactions were added in Model 4. Significant interactions were plotted using the worksheets developed by Dawson (2014). +1SD and -1SD levels of the moderator and independent variables were used. Simple slope $t$-tests for twoway interactions were also calculated (Dawson, 2014).

\section{Results}

\section{Descriptive and bivariate analyses}

Table 1 provides descriptive information about the study variables. In table 2, we present bivariate correlations. Parental divorce was negatively associated with both the full scale of mother-child and father-child relationship quality. In addition, the full scale of parental conflict was negatively associated with both mother-child and father-child relationship quality.
Table 2. Correlations among the study variables.

\begin{tabular}{llllll}
\hline & 1 & 2 & 3 & 4 & 5 \\
\hline 1.Parental divorce & 1 & & & & \\
2. Child gender (male) & $-.08^{*}$ & 1 & & \\
3.Parental conflict (full) & $.34^{* *}$ & -.10 & 1 & \\
4.Mother-child relationship (full) & $-.08^{* *}$ & $-.10^{* *}$ & $-.32^{* *}$ & 1 \\
5.Father-child relationship (full) & $-.22^{* *}$ & -.004 & $-.43^{* *}$ & $.39 * * 1$ \\
\hline
\end{tabular}

\section{Hierarchical multiple regression analyses}

\section{Mother-child relationships quality}

Results on current mother-child relationships quality are presented in Table 3. As expected (Hypothesis 1), parental divorce was associated with lower mother-child relationships quality (Model 1). When interparental conflict was added (Model 2), parental divorce stopped having a significant effect, and interparental conflict was negatively associated with mother-child relationships quality. This effect remained, even when interactions between both parental divorce and conflict (Model 3) and between child's gender and both family of origin experiences were added (Model 4)

\section{Father-child relationships quality}

Results on father-child relationship quality are shown in Table 4. Again, in support to our expectation, parental divorce was negatively associated with father-child relationships quality. When interparental conflict was added (Model 2), both parental divorce and interparental conflict were associated with lower father-child relationship quality. No sig- 
nificant effects were found for the parental divorce $\mathrm{x}$ interparental conflict interaction term (Model 3). By adding interactions between both parental divorce and child's gender and between interparental conflict and child's gender (Model
4), a significant interaction was found for parental divorce $\mathrm{x}$ child's gender, after controlling for all other variables in the model.

Table 3. Summary of hierarchical multiple regression for variables predicting mother-child relationship quality.

\begin{tabular}{|c|c|c|c|c|c|c|c|c|c|c|c|c|}
\hline \multirow[b]{2}{*}{ Variable } & \multicolumn{3}{|c|}{ Model 1} & \multicolumn{3}{|c|}{ Model 2} & \multicolumn{3}{|c|}{ Model 3} & \multicolumn{3}{|c|}{ Model 4} \\
\hline & $B$ & SE B & $\beta$ & $B$ & SE B & $\beta$ & $B$ & SE B & $\beta$ & $B$ & SE B & $\beta$ \\
\hline \multicolumn{13}{|l|}{ Control variables } \\
\hline Gender (male) & $-.146^{* * *}$ & .041 & -.115 & $-.185^{* * *}$ & .039 & -.145 & $-.185^{* * *}$ & .039 & -.145 & $-.194 * * *$ & .044 & -.152 \\
\hline \multicolumn{13}{|l|}{ Explanatory variables } \\
\hline Parental divorce & $-.184 * *$ & .058 & -.102 & .007 & .058 & .004 & .045 & .078 & .025 & -.005 & .091 & -.003 \\
\hline Interparental conflict & & & & $-.498^{* * *}$ & .046 & -.349 & $-.483^{* * *}$ & .050 & -.338 & $-.461 * * *$ & .064 & -.323 \\
\hline \multicolumn{13}{|l|}{ Interactions } \\
\hline Divorce $\mathrm{x}$ interparental conflict & & & & & & & -.087 & 118 & -.035 & -.090 & 119 & -.036 \\
\hline Divorce $\mathrm{x}$ gender (male) & & & & & & & & & & 131 & 116 & .048 \\
\hline Interparental conflict x Gender (male) & & & & & & & & & & -.055 & .093 & -.025 \\
\hline$R^{2}$ & \multicolumn{3}{|c|}{.033 } & \multicolumn{3}{|c|}{140} & \multicolumn{3}{|c|}{.141} & \multicolumn{3}{|c|}{142} \\
\hline$F$ for change in $R^{2}$ & \multicolumn{3}{|c|}{$3.327 * * *$} & \multicolumn{3}{|c|}{$119.298^{* * * *}$} & \multicolumn{3}{|c|}{542} & \multicolumn{3}{|c|}{665} \\
\hline
\end{tabular}

$¥ p<.10 .{ }^{*} p<.05 .{ }^{* *} p<.01 ; * * *<<.001$

Table 4. Summary of hierarchical multiple regression for variables predicting father-child relationship quality.

\begin{tabular}{|c|c|c|c|c|c|c|c|c|c|c|c|c|}
\hline \multirow[b]{2}{*}{ Variable } & \multicolumn{3}{|c|}{ Model 1} & \multicolumn{3}{|c|}{ Model 2} & \multicolumn{3}{|c|}{ Model 3} & \multicolumn{3}{|c|}{ Model 4} \\
\hline & $B$ & SE B & $\beta$ & $B$ & SE B & $\beta$ & $B$ & SE B & $\beta$ & $B$ & SE B & $\beta$ \\
\hline \multicolumn{13}{|l|}{ Control variables } \\
\hline Gender (male) & -.013 & .047 &,- 047 & -.067 & .043 & -.046 & -.068 & .043 & -.047 & $-.134 * *$ & .048 & -.092 \\
\hline \multicolumn{13}{|l|}{ Explanatory variables } \\
\hline Parental divorce & $-.467 * * *$ & .067 & -.224 & $-.211 * * *$ & .064 & -.101 & $-.290 * * *$ & .086 & -.140 & $-.450 * * *$ & .100 & .216 \\
\hline Interparental conflict & & & & $-.672^{* * *}$ & .050 & -.410 & $-.703^{* * *}$ & .055 & -.429 & $-.746^{* * *}$ & .010 & -.456 \\
\hline \multicolumn{13}{|l|}{ Interactions } \\
\hline $\begin{array}{l}\text { Divorce x interparental } \\
\text { conflict }\end{array}$ & & & & & & & .180 & .131 & .062 & 205 & .131 & .071 \\
\hline $\begin{array}{l}\text { Divorce } \mathrm{x} \text { gender } \\
\text { (male) }\end{array}$ & & & & & & & & & & $.366^{* *}$ & .129 & .116 \\
\hline $\begin{array}{l}\text { Interparental conflict } \mathrm{x} \\
\text { Gender (male) }\end{array}$ & & & & & & & & & & .083 & .102 & .033 \\
\hline$R^{2}$ & & .058 & & & 205 & & & 207 & & & 216 & \\
\hline$F$ for change in $R^{2}$ & & $336^{* * *}$ & & & $517 * * *$ & & & .896 & & & $541 * *$ & \\
\hline
\end{tabular}

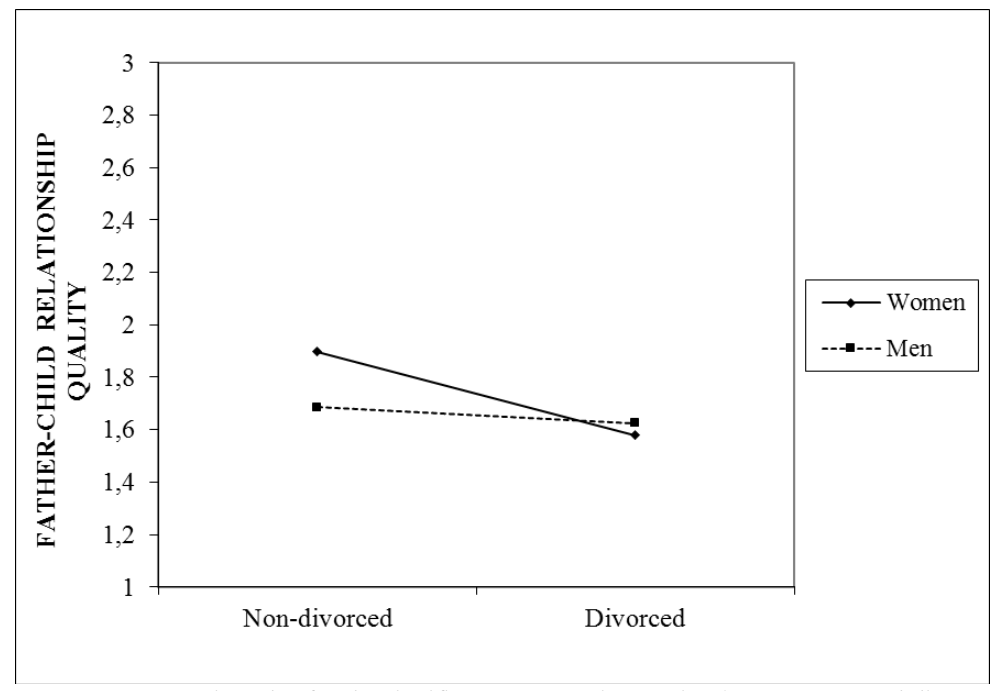

Figure 1. Interaction plot for the significant two-way interaction between parental divorce and adult child's gender on father-child relationship quality. 
Results from the slope difference tests (see Figure 1) showed that Spanish young adult women from non-divorced families score higher on father-child relationship quality than women from divorced families $(t=-4.51, p<.01)$.

\section{Discussion}

The present study analyzed the associations between parental divorce and conflict with both mother-child and father-child relationship quality in a Spanish young adult sample. In addition, the moderating effect of adult child's gender was also analyzed. Five main conclusions emerge from our findings, which confirm most of our expectations.

First, as expected, parental divorce is associated with lower mother child and father-child relationship quality. A second conclusion is that interparental conflict is also associated with a lower relationship quality with both parents. Third, interparental conflict is more strongly associated with both mother-child and father-child relationship quality than parental divorce. However, this conclusion is especially meaningful for mother-child relationship quality. That is, when interparental conflict is added in the regression model parental divorce stops having a significant effect on motherchild relationship, but not on father-child relationship quality. In fact, both parental divorce and conflict concurrently have a significant effect on father-child relationship quality. Fourth, contrary to what we expected, parental divorce and conflict do not interact to explain father-child and motherchild relationship quality. Finally, adult child's gender uniquely moderated the effect of parental divorce on fatherchild relationship quality, such that women, but not men, from non-divorced families score higher on father-child relationship quality than women from divorced families. Below, we discuss in detail these main conclusions.

\section{Parental divorce}

Parental divorce is a life event stressor that has important effects on children's affective relationships. In this vein, our results confirm that adult children of divorce show lower relationship quality with both parents (Amato, 2001; Sobolewski \& Amato, 2007). Stressors associated with the divorce process are usually accompanied by deterioration in parenting of both custodial and non-custodial parents. Custodial parents might be less sensitive to their children's needs and non-custodial parents might diminish their parenting role during the divorce process and the post-divorce period (Hetherington \& Kelly, 2002). All these changes may negatively affect parent-child relationship quality, even in the long term, when children are young adults and are entering a new important developmental stage, as shown by our results. However, our findings suggest a stronger association of parental divorce with father-child relationship quality, which is consistent with several investigations that indicate that father-child relationships are more affected than mother-child relationships by the divorce experience (e.g. Riggio \& Valenzuela, 2011).

Regarding differential effects of parental divorce by child's gender, although some studies have found more negative consequences for the same sex parent-child dyads (Cooney et al., 1995), our results are in agreement with others that have found that opposite sex parent-child ties are more deteriorated by parental divorce in young adulthood (e.g. Booth \& Amato, 1994). That is, although no child gender differences were found for mother-child relationship quality, our findings suggest that daughters of divorce report lower relationship quality with their fathers than daughters from non-divorced families.

\section{Interparental conflict}

Not only parental divorce can affect parent-child relationships, interparental conflict may also have detrimental effects. In fact, research on the associations between interparental conflict and parent-child relationship quality indicates negative and significant associations between parental conflict and both mother-child and father-child relationship quality (e.g. Riggio, 2004). That is, continued exposure to parental conflict might negatively affect parents' ability to function as a secure base and safe heaven with their children, due to the stress related to conflictive interactions. This lower sensitivity might also explain more negative parent-child interactions in young adulthood (Davies \& Cummings, 2006). In our study, parental conflict is associated with more negative father-child and mother-child relationships in young adulthood.

In regards with child's gender differences, even though many studies have shown negative consequences of continued exposure to parental conflict for both opposite sex and same sex parent-child dyads (Amato \& Booth, 1996; Henry \& Holmes, 1997), contrary to what we expected, our findings are in agreement with others that have not found such effects (e.g. Hayashi \& Strickland, 1998). That is, parental conflict is negatively associated with mother-child and father-child relationship quality, regardless of child's gender.

Overall, our results support our predictions about the greater predictive ability of parental conflict than parental divorce on parent-child relationships in young adulthood. However, our findings confirm the deleterious effects of divorce on father-child relationships, as parental divorce is negatively associated with father-child relationship quality, even when parental conflict is accounted. Thus, in agreement with other studies, parental conflict is associated with more negative mother-child and father-child relationship quality, whereas parental divorce is more strongly associated with negative father-child relationship quality, even when parental conflict is taken into account (e.g. Riggio \& Valenzuela, 2011).

In addition, although we expected an interactive effect of parental divorce and conflict on parent-child relationship quality, in agreement with other studies, our findings did not 
suggest such significant interaction (e.g. Riggio, 2004). Therefore, our results are inconsistent with the stress-relief hypothesis (Wheaton, 1990), which suggests that parental divorce might relieve the stress derived from continued exposure to high levels of parental conflict.

\section{Study limitations and contributions}

Our results should be seen in light of several limitations. First, the retrospective and cross-sectional design of this study is a limitation, as it makes it difficult to infer causal conclusions. Adult children of divorce were asked to report on parental conflict prior to divorce. Therefore, reports of interparental conflict provided by adult children of divorce might be influenced by retrospective biases. Therefore, future studies should focus on conducting a longitudinal follow-up design study with a Spanish population, in order to precisely control the actual predivorce parental conflict level. In addition, in our study we uniquely analyzed college and vocational school students. Given the age range of our sample, future studies should replicate this investigation with a broader and more heterogeneous sample. Another limitation has to do with the measure of parental divorce, which was a dichotomous variable assessed by asking participants whether their parents were divorced or separated. Divorce is not a uniform experience for children, and several circumstances surrounding the divorce process might explain the diversity of children's reactions to divorce (e.g. Yarnoz-Yaben \& Garmendia, 2015). Besides, not all parent-child relationships are affected to the same degree by parental divorce. That is, given that several factors surrounding the divorce experience, such as contact and closeness with non-custodial parents, type of custody (e.g. shared or sole custody), parents' distress and adjustment following divorce, the amount of interparental conflict, or diminished financial resources might explain better the effects than divorce per se (e.g. Kelly \& Emery, 2003), further research is needed to examine other variables related to the divorce process, in order to detect factors that might explain variations in the effects of parental divorce on parent-child relationship quality. A final limitation has to do with not examining protective factors, such as authoritative parenting, parents' psychological wellbeing or

\section{References}

Amato, P. R. (1994). Father-children relations, mother-children relations, and offspring psychological well-being in early adulthood. Journal of marriage and the family, 56(4), 1031-1042. http:/doi.org/10.2307/353611

Amato, P. R. (2000). The consequences of divorce for adults and children. Journal of marriage and the family, 62(4), 1269-1287. http:/doi.org/10.1111/j.17413737.2000.01269.x

Amato, P. R. (2001). Children of divorce in the 1990s: An update of the Amato and Keith (1991) meta-analysis. Journal of Family Psychology, 15(3), 355-370. http:/doi.org/10.1037//0893-3200.15.3.355

Amato, P.R. (2014). The consequences of divorce for adults and children: an update. Društvena istraživanja, 23, 5-24. http:/doi.org/10.5559/di.23.1.01

Amato, P. R., \& Afifi, T. D. (2006). Feeling caught between parents: Adult children's relations with parents and subjective well-being. Journal of marriage and family, 68(1), 222-235. http:/doi.org/10.1111/j.1741-3737.2006.00243.x children's effective coping skills that might help explain a reduced effect of both parental divorce and conflict (Amato, 2014; DeBoard-Lucas et al., 2010; Kelly \& Emery, 2003; Lee, 2018). Analyzing these factors might help gather important information to make preventive and clinical intervention efforts to reduce the negative effects of both parental divorce and conflict.

Aside from the limitations of our study, it makes important contributions. First, the most notable one refers to the study of the associations between parental divorce and interparental conflict with mother-child and father-child relationship quality, by testing simultaneously their effect, in a sample where divorce is a relatively new social and family experience. Another important contribution refers to the study of gender differences in the effects of parental divorce and conflict on parent-child relationship quality. That is, the current study specified the gender of parents and young adult children in order to test the effects of parental divorce and conflict. Although some studies have attempted to clarify this gender issue (Yu et al., 2010), there is still a lack of studies on potential gender effects of children on the quality of relationships with each parent. Overall, our findings add to the existing literature, suggesting that interparental conflict is more strongly associated than parental divorce with both mother-child and father-child relationship quality in young adulthood. In addition, parental divorce is more strongly associated with lower father-child relationship quality than with mother-child relationship quality. Gender differences are also found for parental divorce on father-child relationship quality, such that daughters from divorced families report more negative relationships with their parents than those belonging to non-divorced families. Thus, our results suggest that in trying to analyze the negative effects of some negative family of origin experiences, such as parental divorce or conflict, more factors should be considered (e.g. child's gender, age at time of divorce) in order to examine variations in such experiences.

Aknowledgements.- This study was funded by the department of Education, Universities and Research of the Basque Government, through a predoctoral grant (BFI-2011-74).

Amato, P. R., \& Booth, A. (1991). The consequences of parental divorce and marital unhappiness for adult well being. Social Forces, 69(3), 895-914. http:/doi.org/10.1093/sf/69.3.895

Amato, P. R., \& Booth, A. (1996). A prospective study of divorce and parentchild relationships. Journal of marriage and the family, 58(2), 356-365. http:/doi.org/10.2307/353501

Amato, P. R., \& Sobolewski, J. M. (2001). The effects of divorce and marital discord on adult children's psychological well-being. American Sociological Review, 66(6), 900-921. http:/doi.org/10.2307/3088878

Armsden, G. C., \& Greenberg, M. T. (1987). The Inventory of Parent and Peer Attachment: Relationships to well-being in adolescence. Journal of Youth and Adolescence, 16(5), 427-454. http:/doi.org/10.1007/BF02202939

Arnett, J. J. (2015). Emerging adulthood: the winding road from the late teens through the twenties. Oxford University Press. http://dx.doi.org/10.1093/oxfordhb/9780199795574.013.9 
Bartell, D. S. (2006). Influence of parental divorce on romantic relationships in young adulthood: a cognitive-developmental perspective. In M. A. Fine \& J. H. Harvey (Eds.), Handbook of Divorce and Relationship Dissolution (pp. 339-360). Taylor \& Francis Group, LLC.

Bauserman, R. (2002). Child Adjustment in Joint-Custody versus SoleCustody Arrangements: A Meta-Analytic Review. Journal of Family Psychology, 16(1), 91-102. http:/doi.org/10.1037//0893-3200.16.1.91

Booth, A., \& Amato, P. R. (1994). Parental marital quality, parental divorce, and relations with parents. Journal of marriage and the family, 56(1), 21-34. http:/doi.org/10.2307/352698

Booth, A., \& Amato, P. R. (2001). Parental predivorce relations and offspring postdivorce well-being. Journal of marriage and family, 63(1), 197-212. http:/doi.org/10.1111/j.1741-3737.2001.00197.x

Bowlby, J. (1969). Attachment and loss: Attachment (Vol. I). Basic Books.

Bretherton, I. \& Page, T. (2004). Shared or conflicting working models?: Relationships in postdivorce families seen through the eyes of mothers and their preschool children. Development and Psychopathology, 16, 551575. http://dx.doi.org/10.1017/S0954579404004663

Carranza, L. V., Kilmann, P. R., \& Vendemia, J. M. C. (2009). Links between parent characteristics and attachment variables for college students of parental divorce. Adolescence, 44(174), 253-271.

Cooney, T. M., Hutchinson, M. K., \& Leather, D. M. (1995). Surviving the breakup: predictors of parent-adult child relations after parental divorce. Family Relations, 44(2), 153-161. http:/doi.org/10.2307/584802

Cui, M., \& Fincham, F. D. (2010). The differential effects of parental divorce and marital conflict on young adult romantic relationships. Personal Relationships, 17(3), 331-343. http:/doi.org/10.1111/j.14756811.2010.01279.x

Davies, P. T., \& Cummings, M. (2006). Interparental discord, family process, and developmental psychopathology. In D. Cicchetti y D. J. Cohen (Eds.), Developmental psychopathology: risk, disorder and adaptation (Vol. III, pp. 86-128). John Wiley \& Sons, Inc. http://doi.org/10.1002/9780470939406

Dawson, J. F. (2014). Moderation in management research: what, why, when and how. Journal of Business Psychology, 29, 1-19. http:/doi.org/10.1007/s10869-013-9308-7

DeBoard-Lucas, R. L., Fosco, G. M., Raynor, S. R., \& Grych, J. H. (2010). Interparental conflict in context: exploring relations between parenting processes and children's conflict appraisals. Journal of Clinical Child and Adolescent Psychology, $\quad 39(2), \quad 163-175$. http:/doi.org/10.1080/15374410903532593

Feeney, B.C. \& Monin, J.K. (2016). Divorce through the lens of attachment theory. In J. Cassidy \& P.R. Shaver (Eds.), Handbook of Attachment: theory, research and applications (pp. 941-965). The Guilford Press.

Fraley, R. C., \& Heffernan, M. E. (2013). Attachment and parental divorce: a test of the diffusion and sensitive period hypotheses. Personality and Social Psychology Bulletin, 39(9), 1199-1213. http:/doi.org/10.1177/0146167213491503

Grych, J. H., Seid, M., \& Fincham, F. D. (1992). Assessing marital conflict from the child's perspective: The Children's Perception of Interparental Conflict Scale. Child Development, 63(3), 558-572. http:/doi.org/10.1111/j.1467-8624.1992.tb01646.x

Hannum, J. W., \& Dvorak, D. M. (2004). Effects of family conflict, divorce, and attachment patterns on the psychological distress and social adjustment of college freshmen. Journal of College Student Development, 45(1), 27-42. http:/doi.org/10.1353/csd.2004.0008

Hayashi, G. M., \& Strickland, B. R. (1998). Long-term effects of parental divorce on love relationships: Divorce as attachment disruption. Journal of Social and Personal Relationships, 15(1), 23-38. http:/doi.org/10.1177/0265407598151002

Henry, K., \& Holmes, J. G. (1997). Childhood revisited: the intimate relationships of individuals from divorced and conflict-ridden families. In W. S. Rholes \& J. A. Simpson (Eds.), Attachment theory and close relationships (pp. 280-316). The Guilford Press.

Hetherington, E. M., \& Kelly, J. (2002). For better or for worse: Divorce reconsidered. Norton.

Iraurgi, I., Martinez-Pampliega, A., Iriarte, L., \& Sanz, M. (2011). Modelo cognitivo-contextual del conflicto interparental y la adaptación de los hijos [A cognitive-contextual framework of the marital conflict and children's adjustment] Anales De Psicologia, 27(2), 562-573.

Iraurgi, I., Martínez-Pampliega, A., Sanz, M., Cosgaya, L., Galíndez, E., \& Muñoz, A. (2008). Escala de Conflicto Interparental de los Hijos (CPIC): Estudio de validación de una versión abreviada de 36 ítems [Children's Perception of Interparental Conflict Scales (CPIC): Validation study of a sort version of 36 items]. Revista Iberoamericana de Diagnóstico y Evaluación Psicológica, 1(25), 9-34.

Kelly, J. B., \& Emery, R. E. (2003). Children's adjustment following divorce: Risk and resilience perspectives. Family Relations, 52(4), 352-362. http:/doi.org/10.1111/j.1741-3729.2003.00352.x

King, V. (2002). Parental divorce and interpersonal trust in adult offspring. Journal of marriage and family, 64(3), 642-656. http:/doi.org/10.1111/j.1741-3737.2002.00642.x

Lee, S.A. (2018). Parental divorce, relationships with fathers and mothers, and children's romantic relationships in young adulthood. Journal of Adult Development, 25(2), 121-134. http:/doi.org/10.1007/s10804-0179279-4.

Monè, J. G., \& Biringen, Z. (2006). Perceived parent-child alienation: empirical assessment of parent-child relationships within divorced and intact families. Journal of Divorce and Remarriage, 45(3/4), 131-156. http:/doi.org/10.1300/J087v45n03_07

Nielsen, L. (2011). Shared Parenting After Divorce: A Review of Shared Residential Parenting Research. Journal of Divorce and Remarriage, 52, 586609. http:/doi.org/10.1080/10502556.2011.619913

Riggio, H. R. (2004). Parental marital conflict and divorce, parent-child relationships, social support, and relationship anxiety in young adulthood. Personal Relationships, 11(1), 99-114. http:/doi.org/10.1111/j.1475-6811.2004.00073.x

Riggio, H. R., \& Valenzuela, A. M. (2011). Parental marital conflict and divorce, parent-child relationships, and social support among LatinoAmerican young adults. Personal Relationships, 18(3), 392-409. http:/doi.org/10.1111/j.1475-6811.2010.01305.x

Ross, J., \& Fuertes, J. (2010). Parental Attachment, Interparental Conflict, and Young Adults' Emotional Adjustment. Counseling Psychologist, 38(8), 1050-1077. http:/doi.org/10.1177/0011000010376094

Sobolewski, J. M., \& Amato, P. R. (2007). Parents' discord and divorce, parent-child relationships and subjective well-being in early adulthood: Is feeling close to two parents always better than feeling close to one? Social forces, 85(3), 1105-1124. http:/doi.org/10.1353/sof.2007.0056

Sturge-Apple, M. L., Davies, P. T., \& Cummings, E. M. (2006). Impact of hostility and withdrawal in interparental conflict on parental emotional unavailability and children's adjustment difficulties. Child Development, 77(6), 1623-1641. http:/doi.org/10.1111/j.1467-8624.2006.00963.x

Sutherland, K.E., Altenhofen, S. \& Biringen, Z. (2012). Emotional availability during mother-child interactions in divorcing and intact married families. Journal of Divorce and Remarriage, 53, 126-141. http://dx.doi.org/10.1080/10502556.2011.651974

Wallerstein, J.S., Lewis, J., \& Packer Rosenthal, S. (2013). Mothers and their children after divorce: Report from a 25-year longitudinal study. $\begin{array}{llll}\text { Psychoanalitic } & \text { Psychology, } & 30, & 167-184\end{array}$ http://dx.doi.org/10.1037/a0032511

Waters, E., Merrick, S., Treboux, D., Crowell, J., \& Albersheim, L. (2000). Attachment security in infancy and early adulthood: A twenty-year longitudinal study. Child Development, 71(3), 684-689. http:/doi.org/10.1111/1467-8624.00176

Wheaton, B. (1990). Life Transitions, Role Histories, and Mental Health. American sociological review, 55(2), 209-223. http:/doi.org/10.2307/2095627

Yárnoz-Yaben, S., \& Garmendia, A. (2015). Parental divorce and emerging adults' subjective well-being: The role of "carrying messages". Journal of Child and Family Studies, 25(2), 638-646. http:/doi.org/10.1007/s10826015-0229-0

Yu, T. Y., Pettit, G. S., Lansford, J. E., Dodge, K. A., \& Bates, J. E. (2010). The Interactive Effects of Marital Conflict and Divorce on Parent Adult Children's Relationships. Journal of marriage and family, 72(2), 282292. http:/doi.org/10.1111/j.1741-3737.2010.00699.x 